\title{
THE PRESIDENT
}

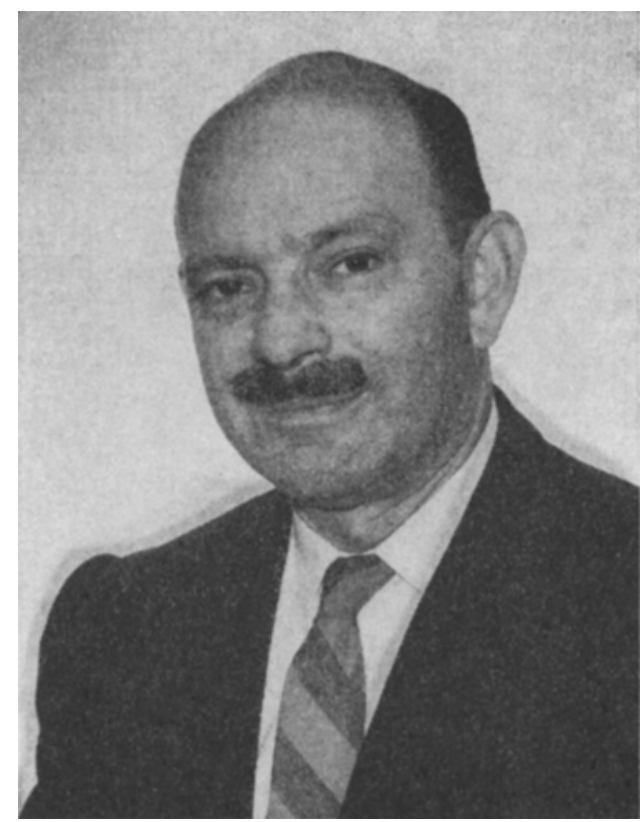

Gordon MichaEL Wyant, C.D., M.D., F.R.C.P. (C), F.F.A.R.C.S.

Dr. Gordon wyant was installed as President of the Canadian Anaesthetists' Society by Dr. Norman McMillen, the Retiring President, on the occasion of the Annual Dinner of the Society at Quebec City on July lst, 1971.

Dr. Wyant was born at Frankfurt, Main, Germany on March 28, 1914. After elementary and high school education in his native city he attended Medical School at the University of Bologna in Italy, where he qualified as Dootor of Medicine in 1938. Moving to Britain in 1939, he entered Queen's College, Birmingham, where he was enrolled in courses in Medicine at Birmingham University and in Theology at Queen's College. He was commissioned in the Royal Army Medical Corps in 1943, and remained in the Service until 1947, retiring with the rank of Lieutenant Colonel. He was appointed Graded Anaesthetist in 1944 and Specialist Anaesthetist in 1946.

In 1944 he was married to Miss Anne Dunnett. The Wyants now have five sons.

On return to civilian life Dr. Wyant served in several House Appointments in Hospitals in Britain. In 1949 he emigrated to Chicago, and in 1950 became Assistant Professor of Anaesthesia at University of Illinois. In 1953 he was appointed head of the Division of Anaesthesia, Stritch School of Medicine of Loyola University and Director of Anaesthesia Mercy Hospital, Chicago. He was appointed Professor of Anaesthesia, University of Saskatchewan in 1954 and Chief of Anaesthesia, University Hospital Saskatoon, which appointments he still holds.

In addition to these important duties Dr. Wyant has contributed much to a wide range of other important activities within his profession and in the community.

From 1947 to 1949 he was an officer in the Territorial Army in Britain. On arrival in Canada he transferred his interest in Military Medicine to the Royal Canadian Army Medical Corps (Militia) and commanded 20 Medical Company in Saskatoon. He has been active in the affairs of the Defence Medical Association of Canada and serves on its 
Executive Committee. He is presently Consultant in Anaesthesia to the Canadian Forces Medical Council.

An active member of the Church, Dr. Wyant has been a lay delegate to the General Synod of the Anglican Church in Canada.

With characteristic energy Gordon Wyant has carried a formidable load of important responsibility for other matters in his specialty. In 1951 he was Consultant to the Council of Pharmacy and Chemistry of the American Medical Association. He has been Consultant in Anaesthesia to the Journal of the American Dental Association, corresponding Editor of the Far East Journal of Medicine and has been Associate Editor of Survey of Anesthesiology since 1958. In 1960 he became a Regional Editor of the Canadian Anaesthetists' Society Joumal, member of the Editorial Board in 1969 and Assistant Editor in 1971. He was a member of the Saskatchewan Medical Care Insurance Commission from 1964 to 1966 and has been Director, Municipal Emergency Health Services for the City of Saskatoon since 1967. He has served as an Examiner in Anaesthesia for the Royal College of Physicians and Surgeons of Canada and is a member of the Board of Directors of the Canadian Foundation for the Advancement of Therapeutics. He is a Member or Fellow of a large number of important professional and scientific associations in the United Kingdom, the United States and Canada.

Dr. Wyant has served on Council of the Canadian Anaesthetists' Society since 1965, when he was first elected representative of the Saskatchewan Division. His ability and energy have been recognized by his appointment as chairman of several important Committees of the Society. In 1965 he was appointed to chair a committee on Standardization of Anaesthetic Equipment. Over the intervening years, with the assistance of the Canadian Standards Association, this committee has developed Canadian Standards for many items of anaesthetic equipment, and has given initiative to the establishment of a Committee on Anaesthetic Equipment in the International Standards Organization. The success of this important venture has owed everything to the energy, tenacity and diplomatic skill of Dr. Wyant in carrying the present Canadian Standards forward to completion and in playing a significant role in the International Working Groups in reconciling the views of other members of these committees. Gordon Wyant was a Vice-President of the Society from 1969 to 1971 and over the past three years a member of the Committee charged with the revision of the Constitution and Bylaws. This experience, his intimate knowledge of the problems of the Canadian Anaesthetists' Society and of Anaesthesia in Canada, his energy and demonstrated executive ability all serve to underline the good fortune of the Society in having him as its President during 1971-72. 
Gordon, Michael Wyant C.D., M.D., F.R.C.P.(c), F.F.A.R.C.S.

Le docteur gordon wyant est entré en fonction en qualité de Président de la Société Canadienne des Anesthésistes à l'occasion du dîner annuel de la Société à Québec, le premier juillet 1971; le président sortant de charge, le docteur Norman McMillen lui a cédé le siège présidentiel.

Le Docteur Wyant est né à Frankfurt, Main, Allemagne le 28 mars 1914. Après avoir complété ses études secondaires dans sa ville natale, il a fait ses études de médecine à l'Université de Bologne en Italie où il a obtenu son doctorat en médecine en 1938. En 1939, il était en Angleterre au Queen's College, Birmingham où il a suivi des cours de médecine à l'Université de Birmingham et des cours de Théologie au Queen's Collège. Il a été admis dans le corps de médecine de larmée Royale en 1943 où il est demeuré en service jusqu'en 1947; au moment de se retirer il occupait le rang de Lieutenant Colonel. En 1944, il a été affecté à l'anesthésie et, en 1946, certifié spécialiste en anesthésie.

En 1944, il se mariait à Mademoiselle Anne Dunnett. Actuellement, les Wyant ont cinq fils.

De retour à la vie civile, le Dr Wyant a rempli plusieurs postes dans les hôpitaux de Grande-Bretagne. En 1949, il émigrait à Chicago et, en 1950, il devint assistant-professeur d'anesthésie à l'Université de l'Illinois. En 1953, il a été nommé directeur de la section d'anesthésie à l'école de médecine Stritch de l'Université Loyola et directeur du département d'anesthésie de l'hôpital Mercy de Chicago. C'est en 1954, qu'il a été nommé professeur d'Anesthésie à l'Université de Saskatchewan et chef d'Anesthésie à l'hôpital universitaire de Saskatoon, fonctions qu'il continue à remplir.

En plus de ses nombreuses obligations, le docteur Wyant a largement contribué à une grande variété d'autres activités au sein de la profession et de la communauté. De 1947 à 1949, il était officier de l'armée territoriale en Bretagne. A son arrivée au Canada, il a transporté ses intérêts dans la médecine militaire dans le corps médical de l'armée canadienne (Militia) et il a commandé la Compagnie Médicale 20 à Saskatoon.

Il a participé activement dans l'association médicale de la Défense au Canada et il fait partie de son comité exécutif. Actuellement, il est consultant en anesthésie près du Conseil Médical des Forces Canadiennes.

En qualité de membre actif de l'Eglise, le $\mathrm{Dr}$ Wyant a agi comme délégué laïque au Synode Général de l'Eglise Anglicane au Canada.

Avec une énergie bien personnelle, le Dr Wyant a assumé une grande quantité de lourdes responsabilités dans d’autres domaines de sa spécialité. En 1951, il agissait comme consultant au Conseil de Pharmacologie et de Chimie de l'Association Médicale Américaine. Il a été consultant en anesthésie pour le journal de l'Association Dentaire Américaine; il a été éditeur correspondant du journal de Médecine Far East; depuis 1958, il est éditeur adjoint de Survey of Anesthesiology. En 1960, il est devenu éditeur régional du journal de la Société Canadienne des Anesthésistes, membre du Comité de Rédaction en 1969 et assistant éditeur en 1971. De 1964 à 1966, il a été membre de la Commission de I'Assurance-Maladie de la Saskatchewan et, depuis 1967, il est directeur des Services de Santé d'urgence pour la ville de Saskatoon. Il a agi comme examinateur en anesthésie pour le Collège Royal du Canada et il est membre du bureau de direction de la Fondation Canadienne pour l'Avancement des Thérapeutiques. Il est membre ou associé d'un grand nombre d'importantes associations professionnelles et scientifiques du Royaume-Uni, des Etats-Unis et du Canada.

Depuis 1965, le Dr Wyant fait partie du Conseil de la Société-Canadienne des Anesthésistes alors qu'il a été élu représentant de la division de la Saskatchewan. Son habilité et son énergie lui ont valu la présidence de plusieurs importants comités de la Société: En 1965, il a été nommé président d'un Comité sur la Normalisation de l'instrumentation 
anesthésique. Au cours des années, avec l'aide de l'Association Canadienne de Normalisation, ce Comité a établi des normes canadiennes pour plusieurs pièces de l'outillage anesthésique et, grâce à l'initiative, l'énergie, la ténacité et l'adroite diplomatie du Dr Wyant, la Normalisation Canadienne a été complétée, et il a joué un rôle important au sein des groupes de travail de la Société Internationale de Normalisation en conciliant les opinions des autres membres de ces comités.

De 1969 à 1971, le Dr Wyant a agi comme vice-président de la Société et, au cours des trois dernières années, il était membre du Comité mandaté de faire la revision de la charte et des règlements. Cette expérience, sa connaissance approfondie des problèmes de la Société Canadienne des Anesthésistes et de l'Anesthésie au Canada, son énergie et ses qualités d'administrateur habile, tout souligne la bonne fortune de la Société de l'avoir comme Président au cours de l'année 71-72.

R. A, GORDON 